\title{
Election Administration in New York City: Pruning the Political Thicket
}

On June 20, 1972, Allard K. Lowenstein ${ }^{1}$ was defeated in his attempt to wrest from incumbent Congressman John J. Rooney the Democratic nomination to the United States House of Representatives in New York's 14th congressional district. ${ }^{2}$ The final tabulation of votes indicated that Lowenstein had lost the Democratic Party primary by 890 out of nearly 30,000 votes cast. ${ }^{3}$

Suspecting that massive electoral fraud had occurred, Lowenstein filed suit to have the primary overturned. ${ }^{4}$ Although initially rejected, ${ }^{5}$ Lowenstein's legal challenge was successful on appeal. ${ }^{6}$ Concluding that the June 20 primary did not meet the "requisite standards" of fair elections in a democracy, the Appellate Division of the New York

1. Lowenstein had been elected to the U.S. House of Representatives in 1968 from New York's fifth congressional district in suburban Nassau County. See N.Y. Times, Nov. 6, 1968, at 27, col. 7. Two years later the New York state legislature, which was controlled by Republicans, redrew the boundary lines of the fifth district in what has generally been viewed as a calculated attempt to unseat Lowenstein. See M. BARONE, G. Ujifusa \& D. Matthews, The Almanac of American Politics-1974, at 659 (1973) [hereinafter cited as ALMANAc]. The gerrymander was successful and Lowenstein lost his bid for reelection. See N.Y. Times, Nov. 4, 1970, at 1 , col. 7 . Accepting a draft from the reform elements of the Democratic Party in Brooklyn, Lowenstein returned to New York City in 1972 to run for Congress against John J. Rooney. See N.Y. Times, Mar. 18, 1972, at 35, col. 4; id., Mar. 28, 1972, at 25, col. 1 .

2. John J. Rooney was first elected to the House of Representatives in 1944. Currently the third ranking member of the powerful Appropriations Committee, he chairs the subcommittee that supervises the Departments of State, Justice and Commerce. See Almanac, supra note 1 , at 680-81; Jt. Comm. on Printing, Congressional Directory 127, 187 (1974). After his reelection in 1972, Representative Rooney became seriously ill. Acceding to pressure from the regular Brooklyn Democratic organization, he announced his retirement in June 1974. See N.Y. Times, June 4, 1974, at 1, col. 7; id., Feb. 4, 1974 , at 19 , col. 3 .

3. Statement and Return of the Votes for the Offices of Kings County, Democratic Party Primary, June 20, 1972 (on file with the Yale Law Journal).

4. See N.Y. Times, June 23,1972 , at 19, col. 1 .

5. Lowenstein v. Larkin, Civil No. $16590-72$ (N.Y. Sup. Ct. Aug. 31, 1972), rev'd mem., 40 App. Div. 2d 604, 335 N.Y.S.2d 799, aff'd mem., 31 N.Y.2d 654, 288 N.E.2d 133, 336 N.Y.S.2d 249 (1972).

6. 40 App. Div. 2d at 604, 335 N.Y.S.2d at 799. The journey of the Lowenstein case through the courts was unusually rapid. Justice Rubin of the New York State Supreme Court ruled against Lowenstein in a decision dated August 31, 1972. Oral argument was heard by the Supreme Court's Appellate Division on September 5 , and Justice Rubin's ruling was reversed on September 7. The New York State Court of Appeals affirmed the Appellate Division decision on September 13. The special election was held six days later. 
Supreme Court ordered a special primary to be held on September 19, 1972.7

At the special election, Lowenstein and his supporters experienced many of the same irregularities that had occurred before, and the final tally of votes that day indicated that Lowenstein had lost again. ${ }^{8}$

The question of whether or not John Rooney was renominated in two primary elections actually won by Allard Lowenstein is one question that may never be satisfactorily answered. ${ }^{9}$ This Note addresses a larger question posed by the Lowenstein-Rooney primary: can an insurgent, or reform, political candidate be assured a fair election under current New York law? ${ }^{10}$ This Note will first demonstrate that the New York Election Law cannot guarantee electoral fairness because it fails in practice to regulate political competition in New York City. In light of this, it will then be argued that because of the particular political situation in New York City, the system of election administration established by the New York Election Law leads to violations of the First and Fourteenth Amendments. ${ }^{11}$

7. 40 App. Div. 2d at 605, 335 N.Y.S.2d at 799. For a discussion of the legal standards applied by New York courts to election challenges based on state law, see Note, Primary Challenges in New York: Caselaw Coleslaw v. Election Protection, 73 ColuM. L. REv. 318 (1973).

8. See N.Y. Times, Sept. 21, 1972, at 41 , col. 1. Lowenstein was on the ballot in the general election as the Liberal Party candidate, receiving approximately 28 percent of the vote in a three-way race. See id., Nov. 9, 1972, at 28, col. 5 .

9. The Appellate Division held that the first election had been "characterized by such ... irregularities as to render impossible a determination as to who rightfully was nominated." 40 App. Div. 2d at 604,335 N.Y.S.2d at 799, quoting N.Y. ELECTION LAw § 330(2) (Mckinney 1964).

10. As used in this Note, terms such as "insurgent," "reform," and "regular," have a special meaning in the context of New York City politics. These terms refer to the conflict between the Democratic Party's two competing factions-the majority "regular" faction, which is committed to organizing the party as an old style political machine, and the minority "reform" faction, which prefers a less authoritarian party structure. This internecine dispute has so dominated Democratic Party politics in New York City that Professor Wilson has termed the history of the party a "history of insurgency." J. Wilson, The Amateur Democrat 32-64 (1970) (especially at 36). See generally E. CostiKYAN, BEHIND Closed Doors (1966). For a discussion of the regular faction at its height, see A. Conarle \& E. Silberfarb, Tigers of Tammany (1967) (Democratic Party leadership in Manhattan).

Despite the infamy of Tammany and its bosses, the regular Democratic organization in Kings County (Brooklyn) has actually dominated the politics of the city for a longer period of time. W. SAYRe \& H. KAUfman, Governing NEw York City 688-89 (1960). It was this organization-the Brooklyn machine-Lowenstein challenged by opposing Representative Rooney.

11. This Note does not contend that all statutory schemes similar to the New York law are unconstitutional per se. The validity of any statute would depend upon whether its provisions accurately reflected the divergence of political viewpoints in the particular state. For instance, a statute placing election administration in the hands of the leaders of a state's two major parties, as New York's does, may be permissible where the significant political forces in the state are reflected in, and channelled through, those two major parties. On the other hand, if the two major parties are opposed from within by internal factions and from without by minor parties and independents, then those elements of the electorate are in danger of having their 


\section{The Lowenstein-Rooney Primary: A Case Study in the Inadequacy of the Election Law ${ }^{22}$}

On June 20, 1972, both the Democratic and Republican parties held primary elections in New York. These elections were administered by election officials selected according to the current New York

constitutional rights infringed by the imposition of unequal burdens and the unfair administration of elections.

Whether the danger is merely speculative, or whether fundamental voting rights are actually jeopardized by a state's election law is a determination of fact based on a particular political situation. In the past, courts have looked beyond the facial provisions of election laws to consider the relationship of their provisions to the political dynamics of a particular situation. See, e.g., Bullock v. Carter, 405 U.S. 134, 143, 146 (1972) (candidacy filing fees must be examined in a "realistic light," and judicial notice may be taken of the fact that the Texas primary election is of greater political importance than the ensuing general election); Williams v. Rhodes, 393 U.S. 23, 32 (1968) (recognition that a facially neutral law favoring a "two-party system" actually grants a monopoly to two particular parties-the Democrats and Republicans).

Viewing in a "realistic light" the political situation in New York City, this Note argues that the New York Election Law is invalid under both the Equal Protection and Due Process Clauses of the Fourteenth Amendment. Specifically, the statute may be unconstitutional in any of three ways: (1) It could be found to contravene fundamental rights in a specific instance, and a new election could be ordered in the particular situation; (2) it could be invalidated because its general application has led repeatedly and consistently to violations of constitutional rights; (3) it could be found to be unconstitutional on its face, regardless of its actual effect in practice.

Although it is not contended here that the New York Election Law is facially unconstitutional, a realistic consideration of its continued and virtually uniform effect leads to the conclusion that it should be invalidated in general application rather than only in specific instances. This is the only effective form of judicial relief for protecting fundamental constitutional rights which cannot meaningfully be vindicated through individual litigation challenging each instance of unfairness. See p. 82 infra; Allee $v$. Medrano, 414 U.S. 1020 (1974) (police misconduct arising under both unconstitutional statutes and unconstitutional application of valid laws enjoined); Storer v. Brown, 415 U.S. 724 (1974) (constitutional challenge to California petition requirement for independent candidates remanded to district court for specific findings as to the statute's effect "in the context of California politics"); Weiss v. Duberstein, Civil No. C70.1200 (S.D.N.Y. Oct. 5, 1970), rev'd, 445 F.2d 1297 (2d Cir. 1971), remanded, Civil No. C70-1200 (S.D.N.Y. Sept. 1, 1971), aff'd, 465 F.2d 1405 (2d Cir.), cert. denied, 409 U.S. 876 (1972) (court order, following ruling that the New York Election Law was in part unconstitutional, tailored to have narrow application).

12. Although the Lowenstein-Rooney June 1972 primary may be the most dramatic example of an unfairly administered election, it is by no means unique. Earlier this year, for example, a Manhattan school board election was invalidated and a new election was ordered by Federal District Judge Charles E. Stewart; Jr. Citing many of the same types of irregularities that characterized the Lowenstein-Rooney election, Judge Stewart held that the substantial discrimination that had occurred required a new election. Coalition for Educ. in Dist. One $v$. Board of Elections, 370 F. Supp. 42 (S.D.N.Y.), aff'd, 495 F.2d 1090 (2d Cir. 1974).

Biased election administration is not a recent phenomenon in New York City. In 1940 the New York City Commissioner of Investigation completed a two-year study of the city's Board of Elections. In the course of this investigation, his staff examined 1900, or 12 percent, of the 15,640 election inspectors appointed in 1937. The examination revealed that 197 inspectors were, themselves, district captains for their party; 328 inspectors had been recommended by district captains who were either their brother, sister, mother, father, or uncle; 567 inspectors were politically active, in that they canvassed or solicited petitions for particular candidates; 461 inspectors admitted that they were required to join a political club and pay dues as a condition to obtaining their job. In his report to the Mayor, the Commissioner concluded that the "likelihood of prejudicing the public's right to impartial elections in favor of the party's self-interest in winning the election is greatly increased" under such a system. W. HERLANDS, ADMiNistration of the ElECtion LAW IN NEW YORK CITY 26 (1940). 
Election Law. ${ }^{13}$ Unfortunately, this statute failed to insure the fairness of the Democratic primary in Brooklyn's 14th congressional district. In fact, the Appellate Division of the New York Supreme Court found that during the June primary, the election inspectors totally or substantially ignored many of the safeguards enacted to insure the integrity of the election. ${ }^{14}$ They repeatedly ignored challenges made by Lowenstein poll watchers, refused to question challenged voters under oath, and kept no record of challenges made. ${ }^{15}$ And they allowed 3,681 unqualified voters to cast ballots. ${ }^{16}$ At the same time, they turned away hundreds of voters who had been directed to specific polling places by the Board of Elections. ${ }^{17}$ In some polling places, the election inspectors actively campaigned for Representative Rooney, while intimidating and harassing Lowenstein poll watchers. ${ }^{18}$ Indeed, one member of the Board of Elections publicly endorsed and supported Representative Rooney, while his wife ran on the Rooney slate for district leader. ${ }^{19}$

Lowenstein was also disadvantaged by the manipulation of the mechanics of the election. Despite a statutory requirement to the

13. See pp. 66-67 infra for a fuller description of the manner in which election officials are selected in New York.

14. 40 App. Div. $2 d$ at 604,335 N.Y.S.2d at 800 .

15. Id.

16. Id. It was stipulated by the parties at the Lowenstein trial that the following irregular votes were cast in the June primary:

429 votes by persons who were not enrolled;

1,317 votes by persons who had not voted for at least two years in a general election, and were therefore ineligible;

658 votes in the names of persons whose registration signatures were not in the registration books at the polling places on election day;

496 votes by persons to whom official correspondence from the Board of Elections had been returned as undeliverable by the Post Office, indicating a probable change of residence, perhaps outside of the district;

8 forgeries and/or votes cast twice;

833 public counter discrepancies, i.e., the number of votes recorded by the voting machines in excess of the physical count of voters made by the election inspectors.

Brief for Appellants at 18, Lowenstein v. Larkin, 40 App. Div. 2d 604, 335 N.Y.S.2d 799 (1972). The Appellate Division of the New York Supreme Court cited in its opinion only the public counter discrepancies, the uncompared signature votes, and the votes cast by non-Democrats. The court noted, however, "There is more, but we think the foregoing amply supports our finding that a new election is required." $40 \mathrm{App}$. Div. $2 d$ at 605,335 N.Y.S.2d at 800 .

17. 40 App. Div. 2d at 604,335 N.Y.S.2d at 799.

18. Id. There was testimony at the Lowenstein trial that in at least one instance, Congressman Rooney himself was guilty of this misconduct. Record at 12227-28, Lowenstein v. Larkin, Civil No. 16590-72 (N.Y. Sup. Ct. Aug. 31, 1972).

19. N.Y. Times, Sept. 11, 1972, at 18, col. 3. Election inspectors were no less biased. It was discovered during the Lowenstein trial, for instance, that the "majority of the Democratic party election inspectors were public supporters of incumbent Congressman John Rooney. Out of 286 inspectors in the four principal districts 113 , or 40 percent, had either signed or carried his petitions, and others were active in his campaign." Brief for Appellants at 7, Lowenstein v. Larkin, 40 App. Div. 2d 604, 335 N.Y.S.2d 799 (1972). 
contrary, the Board of Election went out of alphabetical order to list Rooney's name ahead of Lowenstein's on numerous ballots. ${ }^{20}$ At a number of polling places in areas favorable to Lowenstein, the Board did not provide for two voting machines, as required by law. ${ }^{21}$ The lack of machines resulted in long lines, forcing many people to wait several hours to vote and causing others to give up. ${ }^{22}$ The Chief Clerk of the Board of Elections testified that there were 350 voting machines at the disposal of the Board that day that went unused. ${ }^{23}$ Eight days before the election the Board moved the location of a polling place solely at the request of a local Democratic Party leader; moreover, notice of this change (and two earlier changes) was not sent to the 7,469 affected voters until less than five days before the election, in violation of $\S 66$ of the Election Law. ${ }^{24}$

In view of the differential treatment Lowenstein received from the Board of Elections and the mistreatment his supporters suffered at the hands of biased inspectors on election day, the Appellate Division of the New York Supreme Court concluded that the election was "conducted so badly . . . that every dictate of fairness and protection of the voters' franchise demands a new election." ${ }^{25}$ The abuses that arose in this contest can be understood only in terms of the state system for conducting primary elections as that system operates in New York City.

20. Brief for Appellants at 13, Lowenstein v. Larkin, 40 App. Div. 2d 604, 335 N.Y.S.2d 799 (1972). If the Board of Elections had arranged the order of candidates' names according to the governing statute, N.Y. ELEcTION LAw \$ 242(a)(7) (McKinney Supp. 1973), Lowenstein's would have appeared ahead of Rooney's on the ballot in a majority of districts. Instead, Rooney was listed ahead of Lowenstein in 113 of 168 election districts. Brief for Appellants at 13, Lowenstein v. Larkin, 40 App. Div. 2d 604, 335 N.Y.S.2d 799 (1972).

Both the courts and legislature in New York have recognized that the order in which a candidate's name appears on the ballot may significantly affect the vote in an election. In 1970 that state's highest court held it unconstitutional for an incumbent to be deliberately given the advantage of being listed ahead of his or her opponent. Holtzman v. Power, 62 Misc. 2d 1020, 313 N.Y.S.2d 904 (Sup. Ct.), aff'd, 34 App. Div. 2d 917,311 N.Y.S.2d 824 , aff'd, 27 N.Y.2d 628,261 N.E.2d 666,313 N.Y.S.2d 760 (1970). In response to this decision, the New York state legislature enacted N.Y. Election LAw $\$ 242(a)(7)$ (McKinney Supp. 1973), which requires the equitable rotation of ballot position.

21. Brief for Appellants at 24, Lowenstein v. Larkin, 40 App. Div. 2d 604, 335 N.Y.S.2d 799 (1972). N.Y. Election LAw $\$ 64.4$ (McKinney 1964) requires two voting machines at every polling place where 800 or more voters are enrolled.

22. There was testimony at the Lovienstein trial that throughout the day in the first election district of the 52d assembly district (where Lowenstein received over 75 percent of the total vote), more than 100 people were waiting in line to vote. Reportedly, dozens left the overcrowded polling place withont voting. Record at 1174-78, Lowenstein v. Larkin, Civil No. 16590-72 (N.Y. Sup. Ct. Aug. 31, 1972).

23. Id. at 148,174 .

24. 40 App. Div. $2 d$ at 605,335 N.Y.S.2d at 800 .

25. Id. at 604, 335 N.Y.S.2d at 799, quoting DeSapio v. Koch, 21 App. Div. 2d 20, 22, 247 N.Y.S.2d 789, 792 (1964). 


\section{New York Election Law}

\section{A. Selection of Election Officials}

The electoral misconduct that occurred in the Lowenstein-Rooney primary is directly related to certain provisions of the New York Election Law. These provisions effectively require the state to rely exclusively on the leadership of the Democratic and Republican parties to produce the personnel needed to conduct its elections. ${ }^{26}$ Section 30 of the New York Election Law provides that in each county of the state, and in the city of New York (which is itself five counties), a Board of Elections be established to administer and supervise nearly every aspect of the electoral process. ${ }^{27}$ Each Board of Elections appoints numerous election inspectors to whom it delegates the responsibility for administering elections at each polling place. ${ }^{28}$ Sections 30 and 31 of the New York Election Law provide that the commissioners of the New York City Board of Elections be appointed by the City Council from recommendations made by the county chairmen of the state's two major political parties. ${ }^{29}$ Furthermore, the county chairmen subsequently submit lists of individuals to be appointed election inspec-

26. See note 29 infra.

27. The New York City Board of Elections consists of ten election commissioners, two from each borough. The duties and powers of these commissioners include: the appointment of clerks and deputies, N.Y. Elecrion LAw \$ 36 (McKinney 1964); removal for cause of appointed election officers, $i d$. $\$ 45$; supervision of all voter registration, $i d$. $\$ \S 66,75,355$; preparation of a challenge list of those who have lost the right to register from a given address, id. $\$ 410$; the creation and alteration of election districts, id. $\$ 64$; determination that a voter is not entitled to an absentee ballot, $i d$. $\$ 118$; determination of objections to a petition or certificate of designation or nomination, id. $\$ 145$. For a general discussion of the role of election officials in election administration, see $J$. HARRIS, Election Administration IN THE UNited States 108-20 (1934); E. Logan, Supervision of the Conduct of Elections and Returns 33-41, 47-54 (1927).

28. The duties and powers of election inspectors include: registration of voters, N.Y. ELECTION LAW $\$ \S 354,365$ (McKinney 1964); opening of polling places on election day, id. \$ 192; determining name, party registration, and address of voters, id. $\$ 201$; providing assistance in voting to illiterate, infirm, disabled or blind voters, id. \$ 199 ; ad. ministering oaths to challenged voters, and questioning voters in regard to qualifications, id. $\$ \$ 224-25$; canvass of ballots returned and proclamation of results, id. $\$ \$ 207-16$. Inspectors are also given the authority to direct the arrest of any person refusing to obey their commands, or who, in their opinion, is guilty of disorderly conduct disturbing the proceedings at any voter registration meeting or polling place. Id. $\$ \$ 161,193.4$. For a discussion of the potential control election inspectors have over the right to vote, see J. Harris, supra note 27, at 126-49; E. LoGAN, supra note 27, at 60.73; Note, Protecting the Right to Vote: A Model Voter Challenge Statute, 78 YALE L.J. 662 (1969).

29. N.Y. Election LAW \& 31 (McKinney 1964) defines the two parties eligible to make recommendations as "the two political parties which at the general election last preceding . . . cast the highest and the next highest number of votes for governor." Despite the statute's neutral language, it is unlikely that any candidate but a Democrat or Republican would poll a sufficient number of votes to finish first or second in the gubernatorial election. Registration figures indicate that 49 percent of New York's voters are Democrats, and 37 percent are Republicans; two percent belong to the Liberal Party, and two percent to the Conservative Party. Aluanac, supra note 1 , at 650 . 
tors to the very same commissioners the county chairmen had earlier recommended for appointment to the Board of Elections. ${ }^{30}$ This statutory scheme essentially limits the pool of potential election commissioners and inspectors to those individuals whose political views are favorable to the majority forces of the Democratic and Republican parties in each county. Given the control the county chairmen exert over the selection process, it is virtually impossible for a representative of a reform faction of either party to receive the recommendation of his county chairman and become an election official. ${ }^{31}$

\section{B. The Purpose of the Statute: An Historical and Political Perspective}

Attempts to identify a statute's original legislative purpose rarely enjoy the usual advantages of hindsight. In this instance, however, both case law and legislative action strongly suggest that New York chose to rely on the state's two major political parties for the production of election officials in order to insure electoral fairness through bipartisan administration of elections.

The sections of the New York Election Law that mandate the bipartisan administration of elections have statutory antecedents as early as $1840 .^{32}$ In 1894 the state legislature passed a statute essentially equivalent to the current election law, the central provisions of which - bipartisan administration based on party control of election officials -were made part of the state constitution in the same year. ${ }^{33}$ Although

30. N.Y. ELEction LAw $\$ 40$ (MICKinney 1964). Laws that give political party leaders the authority to choose individuals for public jobs are by no means unusual in New York. In fact, such laws provide the party leaders with their major source of political patronage. Not only do the county chairmen designate election officials, they also control judgeships and numerous other political appointments. See, e.g., N.Y. Times, April 15, 1974, at 33 , col. 4 .

31. The general practice in New York City is for assembly district leaders to recruit potential election inspectors and send their names to the county chairmen for nomination. Therefore, in the few assembly districts where the reform faction has elected a district leader, the names of reformers have on occasion been submitted, and they have been nominated for appointments. Interview with Anne Feldman, Vice Chairwoman of the New York State New Democratic Coalition, in New York City, June 1, 1974. Although it is thus possible in some cases for a reformer to become an election inspector, it would be highly unusual for a county chairman to recommend a reform member of his party for appointment as an election commissioner. Id.

32. See, e.g., ch. 78, [1840] Laws of N.Y. 63d Sess. 52-58. Although this statute did not specifically require election officials to be of different political views, it did provide for minority representation on election boards. It was not until 1887 that election laws were passed authorizing political party leaders to name election officials for bi-

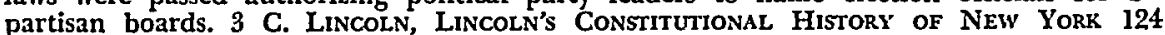
(1906). For a brief historical sketch of the New York state legislature's experimentation with a variety of election administration schemes, see generally id. at 114.31.

33. Compare ch. 348, [1894] Laws of N.Y. 117th Sess. 675-83, with N.Y. Elecrion LAw \$\$ 30, 31, 40, 41 (McKinney 1964). See generally 3 REvised RECORD of THE CoNstitutional Convention of the State of New York 110-16, 244-72, 540-45 (1900). See also C. LincolN, supra note 32 , at $127-31$. 
one delegate to the Constitutional Convention condemned party control over the selection of election officials and objected to a "bipartisan . . . board chosen . . . at the dictation of a lot of cheap ward politicians," 34 the majority view was that bipartisan boards were necessary to secure the "purity of elections." 35 The courts early recognized the statute's purpose. In 1911 the Appellate Division of the New York Supreme Court wrote that it could see a "clear exposition of the purposes of the statute; it is to provide for a bipartisan election board in the city of New York." 36

Viewed as "good government" reforms aimed at insuring electoral fairness to candidates and voters, bipartisanship requirements for election officials were instituted not only in New York but throughout the country during the middle and late 19 th century. ${ }^{37}$ It was believed that electoral fraud and corruption would be best prevented by placing representatives of competing political interests in positions as election officials. $^{38}$ Adoption of bipartisan systems led directly to reliance on party selection of election officials. Any system based on partisanship, including one that attempts to check potential excesses by equalizing partisanship, requires some method of verifying the "interest" of its personnel. Political party leaders were obviously in the best position to provide that certification. Hence, bipartisan administration and party designation of officials were perceived as a means of building into election administration an institutional system of checks and balances. The power of this sentiment is revealed by the fact that currently

34. Revised ReCoRD, supra note 33, at 249 (remarks of Benjamin Dean).

35. Id. at 110 (remarks of Edward Lauterbach). For the amendment in its perfected form, see N.Y. Const. art. II, $\$ 6$ (1894). The amendment has survived, with its provisions virtually intact. See N.Y. CoNST. art. II, \$ 8.

Interestingly, a close study of the debate over the adoption of the 1894 amendment indicates that the Lauterbach proposal was expressly intended to apply only to election inspectors, and not to election commissioners. See REVISED RECORD, supra note 33, at 245, 247. Nevertheless, as subsequent statutes further delineated the separate positions, provisions were regularly made in both cases for the bipartisan requirement and party control over selection. See, e.g., ch. 909, $\S \S 11,12$, [1896] Laws of N.Y. 119th Sess. 904-07; ch. 22, [1909] Laws of N.Y. 132d Sess. 15.

36. Kane v. Gaynor, 144 App. Div. 196, 199, 129 N.Y.S. 280, 283 (1911). This same legislative purpose was reiterated two years later in People ex rel. Woods v. Flynn, 81 Misc. 279, 283, 142 N.Y.S. 230, 232 (Sup. Ct. 1913), where the New York Supreme Court found the "paramount idea of the Legislature by the passage of this law was that these boards of election commissioners should be bipartisan in their character, to the end that the dominant parties in this state should have equal representation on such boards."

Bipartisanship was no less required for election inspectors. A New York court held in 1896 that it was a criminal offense to violate the principle of equal representation on boards of election inspectors. People v. Gleason, 18 Misc. 511, 42 N.Y.S. 1084 (Sup. Ct. 1896).

37. See J. HARRIs, supra note 27, at 114; E. LoGAN, supra note 27, at 4-7 (bipartisanship requirement was enacted in Pennsylvania to "end the increasing struggle between the parties to secure control of the election boards").

38. See J. HARRIs, supra note 27, at 114; E. LOGAN, supra note 27, at 4-7. 
48 states organize their election administrations on a partisan basis; ${ }^{39}$ at least 11 states either permit or specifically provide for multipartisan election administration; ${ }^{40}$ a greater number of states limit election administration to the two major parties; ${ }^{41}$ while only the statutes of California and South Carolina are silent on the issue of the political party affiliation of those who administer elections. ${ }^{42}$

Though theoretically sound, the effort to secure fair elections through bipartisan administration and party selection of election officials has been unsuccessful in New York City. The reason for this failure is that these 19th century regulations have not kept pace with either 20th century electoral reforms or changing political developments. Enactment of a law in 1911 requiring direct primary elections of party nominees, rather than a system of designating candidates

39. Ala. Code tit. 17, $\$ 125$ (1958); Alaska STAt. $\$ 15.10 .150$ (1971); ARIz. Rev. Stat. ANN. \$ 16-77I (1956); ARK. STAT. ANN. \$\$ 3.501, 3-502 (Cum. Supp. 1969); Colo. REV. Stat. AnN. \$49-9-4 (1963); Conn. Gen. Stat. Rev. $\$ \$ 9-190,9-192$ (1967); Del. Code ANn. tit. $15, \S 4731$ (1953); Fla. Stat. ANN. $\$ 102.012$ (Supp. 1973); GA. Code ANN. $\$ 34-501$ (1933); HawaII Rev. STAT. \$ $11-71$ (Supp. 1973); IDAHo CodE § 34-303 (1973); Ill. REv. Stat. ch. 46, § 13-1 (Smith-Hurd 1965); IND. STAT. ANN. \$ 3-1-5-11 (1972); Iowa Code ANN. $\$ 49.12$ (1973); KAN. STAT. ANN. $\$ \$ 25-2802$, 25-2803 (1973); KY. ReV. Stat. \$ 116.070 (1971); LA. Rev. Stat. \$ 18:555 (Supp. 1974); ME. Rev. Stat. ANN. tit. 21, § 532 (1964); MD. ANN. Code art. 33, § 2-1 (Cum. Supp. 1973); Mass. ANN. Laws ch. 54, \$118 (1971); Mich. Comp. Laws ANN. \$ 168.674 (1967); Minn. Stat. ANn. $\$ 203.21$ (Supp. 1974); Miss. Code ANN. \$ 23-5-99 (1972); Mo. ANN. STat. $\$ \$ 111.181$, 191 (Supp. 1974); Mont. Rev. Codes ANN. \$ 23-604 (1947); NEb. Rev. STAT. \$ 32-404 (1968); Nev. Rev. Stat. ANN. \$293.217 (1963); N.H. Rev. Stat. ANn. \$ 59:30 (1955); N.J. Stat. ANn. \$ 19:6-3 (Supp. 1974); N.M. Stat. ANn. \$ 3-2-9 (Supp. 1973); N.Y. Elecrion Law $\$ \$ 30,31,40$ (McKinney Supp. 1972); N.C. Gen. STAT. \$ 163-41 (Supp. 1973); N.D. CENT. Code $\$ 16-10-08$ (Supp. 1971); OHIo Rev. Code ANN. \$ 3501.06 (Page 1953); OKLA. STat. ANN. tit. 26, $\$ 32$ (1951); Ore. Rev. Stat. $\$ 246.310$ (1967); PA. Stat. ANN. tit. 25, \$\$ 2671, 2675 (1963); R.I. GEN. LAwS ANN. \$ 17-11-11 (1969); S.D. CoMpILEd LAws ANN. 1. -15-1, -3 (1967); TENN. CODE ANN. \$ 2-1109 (1955); TEX. EleCTION Code, art. 3.01 (1952); Utah CoDE ANN. \$ 20-7-10 (1953); VT. STAT. ANN. tit. 17, \$§ 1003, 1005 (1957); VA. Code ANN. \$ 24.1-106 (1950); Wash. Rev. Code ANN. $\$ 29.45 .010$ (1965); W. VA. Code ANn. $\$ 3-1-28$ (1966); Wis. Stat. A.in. $\$ 7.30$ (Supp. 1973); Wyo. Stat. AnN. $\$ 22.13(1957)$.

40. Fla. Stat. ANN. tit. 15, \$ 4731 (1953); GA. CODE ANN. \$ 34-501 (1933); Hawair REv. STAT. \$ 11-71 (1968) (Supp. 1973); IDAHO CODE \$ 34-303 (1973); IOWA CODE ANN. $\$ 49.12$ (1973); L.1. Rev. Stat. \$ 18:555 (Supp. 1974); Me. Rev. Stat. Ann. tit. 21, § 532 (1964); N.C. Gen. STAt. \$ 163.41 (Supp. 1973); OKLa. Stat. ANn. tit. 26, \$ 32 (1951); S.D. Compiled Laws ANn. 12-15-1, -3 (1967); VT. Stat. ANN. tit. 17, $\$ \$ 1003,1005$ (1957). 41. See, e.g., Ill. Anv. STAT. ch. 46, \$ 13-1 (Smith-Hurd 1965); Ind. STAT. ANN. \$ 3-1-5-11 (1972); KAN. STAT. ANN. \$§ 25-2802, 25-2803 (1973); KY. REv. STAT. \$ 116.070 (1971); MD. Ann. Code art. 33, \$ 2-I (Cum. Supp. 1973); Minn. Stat. AnN. \$ 203.21 (Supp. 1974); Mo. ANN. Stat. \$\$ $111.181, .191$ (Supp. 1974); Neb. REV. STAT. \& 32-404 (1968); N.H. REv. STAT. ANN. $\$$ 59:30 (1955); N.Y. EleCrion LAw $\$ \S 30,31,40$ (McKinney Supp. 1973); OHIo Rev. CODE ANN. \$ 3501.06 (Page 1953); R.I. GEN. Laws ANN. \$ 17-11-11 (1969); TENN. Cone ANN. \$2-1109 (1955); VT. ST.IT. ANN. $\$ \S 1003$, 1005 (1957); WAsh. REv. Code ANN. $\$ 29.45 .010$ (1965); W. VA. ConE ANN. \$ 3-1-28 (1966).

42. In South Carolina the governor appoints county boards of election upon the recommendation of state senators and representatives from each county. The board members then appoint managers for each polling place. These positions require no prerequisites as to qualifications or party membership. S.C. ConE ANN. $\$ 23-306$ (1962). California elections are administered by the Secretary of State through nonpartisan officials, such as the county clerk or registrar of voters. The position of election inspector is open to all registered voters who file applications for appointment. CAL. ELECIIONS CoDE $\$ 1615$ (West 1961). 
through a party convention proceeding, was the legislation that first undercut the system of safeguards attempted by the earlier reforms. The emergence of the Democratic Party, and thus the Democratic Party primary, as the dominant force in New York City politics has further compounded the problem.

\section{Development of the Direct Primary Election}

Nineteenth century legislators appear to have been generally unconcerned about regulating intraparty competition. ${ }^{43}$ Early party primaries were considered internal, almost private, party matters, and as such were left virtually unsupervised. ${ }^{44}$ The New York Election Law of 1887 allowed parties to prescribe their own voter qualifications, and therefore party leaders could effectively prevent dissident party members from voting in primary elections. ${ }^{45}$ Although initial legislative attempts to reform the primary system proved unsuccessful, ${ }^{40}$ dissatisfaction with such tightly controlled party primaries ultimately led to the passage in 1911 of a law requiring the direct election by the voters of all party candidates except those seeking statewide office. ${ }^{47}$ Direct primary elections were a revolutionary innovation in New York politics that promised to "permit the voters to construct the [party] organization from the bottom upwards, instead of permitting leaders to construct it from the top downwards." 48

\section{Defects in the New York Election Law}

Both the move toward bipartisan election supervision and the requirement of direct primaries represent legislative responses to reform

43. This legislative indifference is revealed by the fact that no regulation of party primaries even existed until 1882. Ch. 154, [1882] Laws of N.Y. 105th Sess. 188-89, is New York state legislature's first attempt to regulate the conduct of party primaries. The statute enacted the most basic restrictions, declaring illegal such activity as ballot box stuffing, intimidation and impersonation of voters, and the destruction of ballots.

44. L. Abrahams, New York Election Law Manual With Forms 83 (1939): "Prior to 1911 under the rules which then allowed the political party organization in power to conduct its own private primaries unsupervised, it permitted the election of delegates at the primary elections. These delegates, in turn, met at different conventions and made nominations. The organization men generally nominated any candidate whom the leader might select." See also B. Gassman, Election Law 37 (1957); F. DaLLiNGer, Nominations For Elective OfFice iN the United States 95-110 (1897).

45. Ch. 265, [1887] Laws of N.Y. 110th Sess. 329-333. However, it was soon recog: nized that the power to "prescribe tests or qualifications for a voter was . . employed ... to exclude from participation in the primary ... members of a minority faction in the party." People ex rel. Coffey v. Democratic Comm., 164 N.Y. 335, 340, 58 N.E. 124, 125 (1900) (Parker, Ch. J.).

46. In 1898 the state legislature limited the power of political parties to set voter qualifications for primaries, permitting only the requirement that voters make a general expression of intent to stuport the party and its candidates. Ch. 179, [1898] Laws of N.Y. 121st Sess. 331-59. See also notes 38, 43 supra.

47. Ch. 891, [1911] Laws of N.Y. 134th Sess. 2681-82.

48. People ex rel. Coffey v. Democratic Comm., 164 N.Y. 335, 342, 58 N.E. 124, 126 (1900). 
impulses aimed at regulating political competition. Ironically, at the same time the legislature recognized the critical importance of intraparty contests and sought to free them from the control of party leaders by mandating a direct primary, legislative acceptance for primary elections of a statutory scheme designed to regulate general elections allowed that domination to continue.

This unfortunate consequence resulted from the failure to recognize the fundamental difference between primary and general elections. Although a law providing for bipartisan representation and party designation of election officials may be effective in a general election, where the interests of the two dominant parties are usually antagonistic, the same cannot be said of primary elections that are necessarily characterized by intraparty factional disputes. Election officials selected in accordance with the New York Election Law cannot help but identify with the faction whose leaders provided their jobs. They therefore have an interest in bringing about a particular result at the primary-the success of their faction's candidates. Moreover, it would be a mistake to think that the Republican members of the Board of Elections and their counterparts on the boards of inspectors vigilantly safeguard the rights of insurgent Democrats. Republican and Democratic election officials often cooperate with one another in order to protect their common interest in maintaining the status quo. ${ }^{49}$ Officials of the opposite party are not sufficiently concerned with the outcome of a factional fight in the ranks of the opposing party to oversee diligently the administration of the election.

The adverse effect resulting from this lack of effective supervision over primaries is magnified in importance because of the significance of the Democratic primary election. Because the Republican Party is substantially outnumbered in New York City, ${ }^{50}$ meaningful com-

49. Interview with David Dinkins, former President of the New York City Board of Elections, in New York City, Nov. 2, 1973. This has been recognized by the media, see N.Y. Times, Sept. 11, 1972, at 42, col. 7 ("Regular organization candidates and their lawyers, whether Democrat or Republican, are welcomed like comrades-in-arms at the Board of Elections offices, while insurgents and rcformers are treated like interlopers and malcontents.") (emphasis supplied).

Such a situation is not a recent development. One commentator has noted that the "theory that each side will watch the other is not valid, for many election frauds are committed with the mutual connivance of the election officers of both parties." J. Harris, supra note 27, at 133. A former City Commissioner of Investigation expressed a similar observation by reporting that, "There are officially recorded instances where the local representatives of one major political organization served as an adjunct to the other." W. Herlands, supra note 12, at 27.

50. New York City contains 18 congressional districts. Two of these districts include substantial portions of nearby suburbs. The average New York City congressional district -excluding the two that straddle the city's borders-has an electorate that is 17 percent Republican and 69 percent Democratic. Eleven of these congressional districts are less than 20 percent Republican, while nine are at least 70 percent Democratic. Brooklyn's 14th congressional district is 71 percent Democratic and only 17 percent Republican. 
petition in the political arena takes place only between rival factions of the Democratic party. Since the Democratic nomination is tantamount to election victory in most races, with the general election merely a ratification of that earlier decision, the Democratic primary is effectively the determinant stage of the electoral process. But it is at just this stage that the guarantees of fairness are absent. By entrusting the selection of election officials to the established party leadership, the law operates to exclude supporters of reform candidates from serving as election officials. The competitive check contemplated by the bipartisan system is therefore completely absent, so that the interests of reform candidates and of individuals wishing to vote for them are unprotected. In effect, then, the New York Election Law operates to allow the regular faction of the Democratic Party inordinate influence not only over the party's nominating procedure but also over the entire electoral process. ${ }^{51}$

\section{The Unconstitutionality of the New York Election Law}

\section{A. Equal Protection Analysis: The Rights to Vote and to Associate}

Despite Justice Peckham's confident assertion in 1904 that the Constitution "does not confer the right of suffrage upon anyone," $v_{2}$ the Supreme Court has since recognized the fundamental nature of the right to vote as "preservative of all other rights." 53 Although there is no constitutionally protected right to vote as such, ${ }^{54}$ the "Court has made clear that a citizen has a constitutionally protected right to participate in elections on an equal basis with other citizens in the jurisdiction." 55

The Supreme Court has not only recognized the right to vote as

Almanac, supra note 1 , at 662-706. The lack of significant electoral competition offered by a Republican congressional candidacy in the 14th congressional district is revealed by the total campaign expenditure of the Republican congressional candidate in 1972-\$270. Common Cause CaMpaign Monitoring Project, CaMpaign Expenditures FOR ALL NoveMBER, 1972 House RACEs 13 (Nov. 1973).

51. Of course, any general election competition generated by minor party and in. dependent candidates and voters is similarly hindered by their exclusion from election administration.

52. Pope v. Williams, 193 U.S. 621, 633 (1904). For an opinion questioning the continued vitality of Pope, see Dunn v. Blumstein, 405 U.S. 330,362 (1971) (Blackmun, $J$., concurring), where it is asserted that the Supreme Court's attempt to "blithely explain away" Pope actually overruled it.

53. Reynolds v. Sims, 377 U.S. 533, at $561-62$ (1964); Yick Wo v. Hopkins, 118 U.S. 356 (1886).

54. Minor v. Happersett, 88 U.S. (21 IVall.) 621 (1894). See also San Antonio School Dist. v. Rodriguez, 411 U.S. 1, 35 n.78 (1973) (Powell, J.); id. at 59 n.2 (Stewart, J., concurring).

55. Dunn v. Blumstein, 405 U.S. 330, 336 (1971). See also San Antonio School Dist. v. Rodriguez, 411 U.S. I, 34 n.74, n.78 (Powell, J.) (1973); id. at 59 n.2 (Stewart, J., concurring). 
fundamental, but has also broadened the scope of protection afforded the right. For many years the Court was primarily concerned with protecting the right to vote from flagrant forms of discrimination. ${ }^{56}$ More recently the Court has shifted its focus from this basic protection of the franchise to making the right to vote more meaningful. ${ }^{57}$ This shift began with the Reapportionment Decisions, in which the Supreme Court promoted the ideal "that as nearly as possible all men should count as one politically, however different their other circumstances." 58 Expressing this idea, Chief Justice Warren stated in Reynolds v. Sims that "each and every citizen has an inalienable right to full and effective participation in the political process." 59 Constitutional protection of voting rights has been extended to include state as well as federal elections ${ }^{60}$ and primary as well as general elections. ${ }^{01}$

56. Accordingly, the Court held to be unconstitutional: the all-white primary, Terry v. Adams, 345 U.S. 461 (1953); Smith v. Allwright, 321 U.S. 649 (1944); ballot box stuffing, United States v. Saylor, 322 U.S. 385 (1944); the failure to count votes honestly, United States v. Classic, 313 U.S. 299 (1911); the intimidation of voters, Ex parle Yarborough, 110 U.S. 651 (1884).

57. See, e.g., A. Reitman \& R. Dividson, The Election Process: Voting Laws and Procedures 80.84, $150-51$ (1972). See generally R. Claude, The Supreme Court and The Electoral Process (1970); Kirby, The Constilutional Right to Vote, 45 N.Y.U.L. REv. $995(1970)$. For perhaps the most eloquent expression of the expansive view of voting rights, see Fortson v. Morris, 385 U.S. 231, 250 (1966) (Fortas, J., dissenting):

It is not merely the casting of the vote or its mechanical counting that is protected by the Constitution. It is the function-the office-the effect given to the vote, that is protected.

A vote is not an object of art. It is the sacred and most important instrument of democracy and of freedom. In simple terms, the vote is meaningless-it no longer serves the purpose of the democratic society-unless it, taken in the aggregate with the votes of other citizens, results in effecting the will of those citizens provided they are more numerous than those of differing views.

58. R. Dixon, Democratic Representation 582 (1968).

59. Reynolds v. Sims, 377 U.S. 533, 565 (1964). The Reapportionment Decisions, along with the congressional districting cascs, e.g., Wesberry v. Sanders, 376 U.S. 1 (1964); Kirkpatrick v. Preisler, 394 U.S. 526 (1969), have provided the constitutional foundation for a broad protection of activities related to voting rights designed to in. sure that all voters can participate in the political process fully and effectively. Seé, e.g., O'Brien v. Skinner, 414 U.S. 524 (1974) (right to vote of individuals detained in prison upheld); Dunn v. Blumstein, 405 U.S. 330 (1972) (durational residency requirements for voters unconstitutional); Phoenix v. Kolodziejski, 399 U.S. 204 (1970) (property ownership cannot be required for voting in general obligation bond election); Evans v. Cornman, 398 U.S. 419 (1970) (residents of a federal enclave permitted to vote in state elections); Cipriano v. City of Houma, 39.5 U.S. 70I (1969) (property ownership requirements for bond issue elections held unconstitutional); Moore v. Ogilvie, 394 U.S. 814 (1969) (burdensome petition requirements held unconstitutional); Williams v. Rhodes, 393 U.S. 23 (1968) (ballot access for minor party candidates protected); Harper v. Virginia Bd. of Elections, 383 U.S. 663 (1966) (poll tax declared unconstitutional); Carrington v. Rash, 380 U.S. 89 (1965) (exclusion of military residents from voting held unconstitutional). But see cases cited at note 67 infra.

60. See, e.g., Baker v. Carr, 369 U.S. 186 (1962); Reynolds v. Sims, 377 U.S. 533 (1964): Anderson v. United States, 415 U.S. 924 (1974) (intent to fraudulently influence a state or local election sufficient to sustain a conviction under a federal conspiracy statute).

6I. See, e.g., Bullock v. Carter, 405 U.S. 134 (1972); Terry v. Adams, 345 U.S. 461 (1953); Smith v. Allwright, 321 U.S. 649 (1944); United States v. Classic, 313 U.S. 299 (1941). 
The Supreme Court has also been solicitous of the right to associate. This right is a substantive freedom derived from the First Amendment. ${ }^{62}$ Recognizing that the right to associate, like the right to vote, is instrumental in the attainment of other fundamental liberties, the Court has protected the right to combine and organize for the advancement of political or social views. ${ }^{63}$

The constitutional protection accorded the rights to vote and to associate has had a powerful impact on statutes regulating electoral activity. This is demonstrated by the Supreme Court's decision in Williams v. Rhodes. ${ }^{64}$ In 1968 the American Independent Party and the Socialist Labor Party challenged the Ohio procedures used to choose electors for President and Vice President of the United States. Plaintiffs alleged that the procedures discriminated against minority parties and thereby violated the Equal Protection Clause of the Fourteenth Amendment. ${ }^{\text {b5 }}$

Writing for the Court, Justice Black characterized the right of association and the right to vote as ranking among "our most precious freedoms," and rejected the justifications advanced by the state as insufficient to allow infringements upon those fundamental rights. ${ }^{61}$ The legal test that emerged from Williams is an exacting one: If a state statute imposes an unequal burden on the fundamental rights to vote and to associate, the statute is unconstitutional under the

62. NAACP v. Alabama, 357 U.S. 449 (1958). See also Shelton v. Tucker, 364 U.S. 479 (1960); Bates v. Little Rock, 361 U.S. 516 (1960); Thomas v. Collins, 323 U.S. 516 (1945); De Jonge v. Oregon, 299 U.S. 353 (1937). See generally C. RICE, FreEdOM oF Association (1962); Emerson, Freedom of Association and Freedom of Expression, 74 YALE L.J. 1 (1964).

63. In NAACP v. Button, 37I U.S. 415 (1963), Justice Stewart wrote that the freedom of association protected the litigation activities of the NAACP because they were directed toward obtaining equality of governmental treatment for all black Americans. Similarly, in United Mine Workers of America v. Illinois Bar, 389 U.S. 217 (1967), the Court struck down a state order prohibiting a union-organized system of delivering legal advice to workers as a violation of the union members' freedom to associate in order to exercise more fully their legal rights.

64. 393 U.S. 23 (1968). Williams was a momentous decision that plunged the judiciary farther into the political thicket than it had ever before ventured. Chief Justice Warren, in a dissent to the majority opinion, compared the potential effect of Iilliams to that of the Court's decision in Baker v. Carr. 393 U.S. at 63. Compare Williams, with Jenness v. Fortson, 403 U.S. 431 (1971) (similar petition requirement statute in Georgia upheld); American Party of Texas v. White, 415 U.S. 767 (1974); Storer v. Brown, 415 U.S. 724 (1974) (ballot access restrictions approved). See generally Barton, More Nominees or More Representalive Nominees?, 22 STAN, L. REv. 165 (1970) (significance of Williams may be that it is the Court's first attempt to construct constitutional norms for the representation of divergent viewpoints within election systems); The Supreme Court, 1968 Term, 83 HARv. L. Rev. 7, 86 (1969); 6 HARv. J. Legis. 236 (1969).

65. The members of the American Independent Party had collected the required number of signatures to place George Wallace's name on the ballot, but not by the statutory deadline. The Socialist Labor Party had failed to obtain sufficient signatures. Both parties were denied a place on the ballot by the Ohio Secretary of State.

66. Williams v. Rhodes, 393 U.S. 23, 30 (1968). 
Equal Protection Clause unless the state can offer a compelling justification for that unequal burden. ${ }^{67}$

The New York law violates equal protection because it infringes upon the fundamental rights to vote and to associate. This occurs in two ways. First, everyone other than a member of the dominant faction of a major political party is excluded in practical effect from serving as an election official. It is unlikely that a party chairman would nominate to a valuable political position ${ }^{88}$ a person who is not a loyal party member. Such preclusion is a burden that regular party members do not bear. Moreover, those people systematically excluded from serving as election officials are forced to exercise their rights in a partisan system that is politically hostile to them. The Lowenstein-Rooney contest demonstrates that voters and candidates who oppose the Democratic machine in New York City do not have an opportunity to participate equally in the election process, ${ }^{69}$ thus resulting in a debasement or dilution of their votes..$^{70}$ Although the abuses that occurred in this primary should not happen under any electoral system, New York law permits these occurrences by its use

67. Id. at 31. The Court has seemingly applied a lesser standard in certain other cases involving voting rights. See, e.g., Richardson v. Ramirex, 94 S. Ct. 2655 (1974); Gaffney v. Cummings, 412 U.S. 735 (1973); White v. Regester, 412 U.S. 755 (1973); Rosario v. Rockefeller, 410 U.S. 752 (1973); Salyer v. Tulare Lake Basin Water Storage Dist., 410 U.S. 719 (1973); Associated Enterprises Inc. v. Toltec Improvement Dist., 410 U.S. 803 (1972). These decisions seem to indicate that although "not every limitation or incidental burden on the exercise of voting rights is subject to a stringent standard of review," Bullock v. Carter, 405 U.S. 134, 143 (1972), only a very limited imposition on the exercise of those rights appears to be constitutionally permissible.

68. Election commissioners are paid a maximum of $\$ 5,000$ per year. N.Y. ELECTION LAw $\$ 33$ (McKinney Supp. 1973). In Weiss v. Duberstein, 445 F.2d 1297, 1301 (2d Cir. 1971), the court observed that only the "politically naive" would conclude that the Democratic and Republican County Committees would use the statute to select anyone but those politically active individuals with whom they were aligned. In 1972, election inspectors earned $\$ 20$ per day. See N.Y. Times, Sept. 25, 1972, at 41, col. 3.

69. Williams v. Rhodes, 393 U.S. 23, 31 (1968) (right of association means little if a political party can be denied "an equal opportunity to win votes").

Admittedly, because of the facts of the case, Williams refers specifically to political parties. This gives rise to the possibility that the holding would not apply to voters and candidates within a faction of an established party, such as lowenstein and his supporters. Although the focus in Williams was on party organizations, it would be difficult to imagine the Court reaching a different decision if the plaintiffs had been individual candidates rather than organized political parties. Burdensome restrictions on the individual candidate would still infringe upon the rights to associate and to cast effective votes.

Despite the traditional judicial reluctance to interfere with the internal affairs of a party, the constitutional mandate of Williams compels such interference in the situation of the New York Election Law. Recognition of the need to protect the right to vote has prompted greater departures from judicial restraint in the past. See, e.g., Terry v. Adams, 345 U.S. 461 (1952); Smith v. Allwright, 321 U.S. 649 (1944). Because of its partisan nature, the New York election machinery effectively denies an effective voice to reformers, independents, and minority party members. The protection of IVilliams ought not to be withheld because of a party designation.

70. Such a debasement or dilution is just as surely a denial of the right of suffrage as if those voters had been prohibited from voting at all. Reynolds v. Sims, 377 U.S. 533,555 (1964). 
of partisan officials who administer elections in an unfair and discriminatory manner.

Given the burdens that the New York law places on the rights to vote and to associate, the statute can be justified only by a compelling state interest. ${ }^{71}$ The original purpose of the New York law was to insure fairness through bipartisanship. ${ }^{72}$ The present statutory scheme, however, fails to serve that purpose in either the primary or the general election. The actual administration of the primary election is highly partisan, with the check of bipartisan supervision completely absent. Since New York City is politically dominated by one party, control of the Democratic primary is essentially control of the outcome of the general election. ${ }^{73}$ Election administration in New York City is thus bipartisan in form only; in substance it is intensely partisan.

Conceivably, there are two other justifications for the statute that might be offered, but neither of them is persuasive. It might be argued, as it was in Williams, that the law ought to be retained because it promotes the two-party system. However, the New York Election Law promotes only the Democratic and Republican parties, ${ }^{74}$ and, as the Court held in Williams, promotion of two particular parties is not a legitimate goal. ${ }^{75}$ In addition, the law may actually encourage the proliferation of minority parties. The present statute concentrates power in the hands of the regular organizations of the Democratic and Republican parties. This power is often exerted at the expense of internal reform factions. Those factions which feel powerless within their own parties may, therefore, seek that power by forming new political parties, thus resulting in an increase in the number of such organizations. $^{78}$

71. If a challenged statute grants the right to vote to some citizens and denies the franchise to others, "the Court must determine whether the exclusions are necessary to promote a compelling state interest." Kramer v. Union Free School Dist., 395 U.S. 621, 627 (1969); Williams v. Rhodes, 393 U.S. 23 (1968).

72. See pp. 67-68 supra.

73. See note 50 supra.

74. See note 29 supra.

75. Williams v. Rhodes, 393 U.S. 23, $31-32$ (1968).

76. See Barton, supra note 64. To argue that the New York Election Law may operate both to discriminate against minor parties and to encourage their growth seems at least superficially contradictory. This seeming inconsistency is reconciled, however, when one realizes that the impact of the statute is different over time and in different political situations. For instance, if the divergent political viewpoints of the electorate are substantially represented by, and channelled through, the two major parties and a number of minor parties, the discriminatory impact occurs. On the other hand, where the political forces in the electorate are organized in such a way that significant political competition expresses itself in a factionalized major party, then over time the statute may encourage the minority faction to forsake its parent party to gain the autonomy of a separate, minor party status. The latter process is 
The other possible justification for the current law is the efficiency of its administration. ${ }^{77}$ The maintenance of an administrative system that subverts the very integrity of elections certainly cannot be tolerated, regardless of its efficiency. Moreover, there is considerable evidence that the present New York City system is woefully inefficient. ${ }^{78}$ Finally, there is no reason to believe that an alternative that would necessitate fewer sacrifices of fundamental rights would not be at least as efficient. ${ }^{79}$

Clearly, none of these possible rationales is sufficiently eompelling to justify the incursions on fundamental rights caused by the unequal burden of the New York Election Law. The statute therefore must be invalidated as violative of the Equal Protection Clause of the Fourteenth Amendment.80

especially significant because the meaningful political competition in New York City is currently organized in such a way that it more closely conforms to the factionalized major party pattern.

77. See, e.g., Bullock v. Carter, 405 U.S. 134, 147-48 (1972) (state's argument that extreme filing fees necessary for the administration of party primaries rejected). The major efficiency factor involved in election administration is the recruitment of the large number of part-time personnel actually needed to serve as inspectors. A federal court hearing a challenge to an Ohio election statute similar to the New York law seemed to be influenced by this consideration. Pirincin v. Board of Elections, $368 \mathrm{~F}$. Supp. 64, 71-72 (N.D. Ohio 1973). The court in Pirincin refused to apply strict scrutiny, holding that the Ohio statutory scheme for selecting board members did not infringe upon the right to vote in that election officials were appointed, not elected. See San Antonio School Dist. v. Rodriguez, 411 U.S. 1, 34 n.78 (1973) (voting rights protection extends only to right to participate on an equal basis with other qualified voters when the state has adopted an elective process) (emphasis supplied); the court also required the plaintiff to demonstrate "inherent bias" on the part of the Board of Elections, which he failed to do. Evidently, examples of bias such as those that occurred in the Lowenstein-Rooney primary were not readily available.

The decision in Pirincin should be no bar to suits challenging election administration laws similar to those in New York and Ohio. It appears that one of the primary reasons for plaintiff's failure was the manner in which he argued the case. Pirincin contended that he had a constitutional right to vote for an election inspector, which was denied him because he was a political independent and the Ohio statute called for party designation of election officials. The outcome of the case might have been different had he argued that there was a constitutional right to be free from discriminatory election administration and that this right was infringed by the effect of the statutory selection of election officials.

78. Election administration is so badly mismanaged in New York that many people believe electoral misconduct is more accurately attributable to nonfeasance than to malfeasance. Interview with David Dinkins, former President of the New York City Board of Elections, in New York City, Nov. 2, 1973. One New York City congressman described the administration of the June, 1972, primary as "total incompetence." 118 CoNG. Rec. E6733 (daily ed. June 30, 1972) (remarks of Rep. Scheuer). See also N.Y. Times, Sept. 25, 1972, at 41 , col. 1 .

79. For a discussion of possible alternatives, see pp. 83-84 infra.

80. In addition to being unconstitutional because it imposes unequal burdens on voting rights, the New York Election Law can also be considered invalid as an impermissible infringement on the fundamental rights of the candidates themselves. The theory that candidates' rights are fundamental is based on the premise that the candidates' right to run is correlative with the citizens' right to vote for them. Because a state statute that regulates candidacies simultaneously restricts the ability of citizens to vote for the candidates of their choice and thereby impinges on fundamental rights, it should be subjected to strict judicial scrutiny. See, e.g., Note, Durational Residence Requirements for State and Local Office: A Violation of Equal Protection?, 


\section{B. Due Process Analysis}

In addition to the denial of equal protection that results from the imposition of unequal burdens upon certain voters and candidates,

45 S. CAL. L. REv. 996 (1972); Note, Equal Protection and Properly Qualifications for Elective Office, 188 U. PA. L. REv. 129, $137-42$ (1969); Comment, The Emerging Right to Candidacy in State and Local Elections, 17 WarNe L. Rev. 1543 (1971). Such rights of candidates may also be based on the theory that political candidacy is a protected activity within the scope of freedom of expression and freedom of association under the First Amendment. See Williams v. Rhodes, 393 U.S. 23 (1968). For an historical argument that the Constitution does not contain a right to candidacy, see Avins, The Right to Hold Public Office and the Fourteenth and Fifteenth Amendments, 18 MERCER L. REv. 367 (1967).

The Supreme Court has never explicitly recognized the rights of candidates. Sec Snowden v. Hughes, 321 U.S. I (1944). Rather, by protecting the rights of voters, the Court has protected candidates' rights without acknowledging their existence. See, e.g., Lubin v. Panish, 415 U.S. 709, 716 (19/4). ("The right of a party or an individual to a place on the ballot is entitled to protection and is intertwined with the rights of voters"); Bullock v. Carter, 405 U.S. 134 (1972) ("[although] initial and direct impact of filing fees is felt by aspirants for office, rather than voters . . . the rights of voters and the rights of candidates do not lend themselves to neat separation; laws that affect candidates always have some theoretical, correlative effect on voters"); Williams v. Rhodes, 393 U.S. 23 (1968) (although the discriminatory procedures directly burdened candidacy, the unequal burden test is derived from burdens placed on the right to vote and associate). Lower courts, however, have recognized such rights. The strongest judicial assertion of a candidate's rights is Shakman v. Democratic Org. of Cook County, 435 F.2d 267 (7th Cir. 1970). The Court of Appeals for the Seventh Circuit held that an independent candidate for a state constitutional convention delegate's seat was denied equal protection of the laws by a patronage system that discriminated against his candidacy. The court held that the alleged official conduct, if proved, violated the plaintiff's right to an "equal chance" in an electoral contest and the voters' right to an "equally effective voice." Id. at 270 . See also White v. Snear, 313 F. Supp. 1100 (E.D. Pa. 1970) (use of a patronage system considered clear violation of equal protection); Stapleton v. Clerk for City of Inkster, 311 F. Supp. 1187 (E.D. Mich. 1970) (right to candidacy protected); Zeilenga v. Nelson, 4 Cal. 3d 716, 94 Cal. Rptr. 602, 484 P.2d 578 (1971) (the right to run for public office is as fundamental as the right to vote); Note, Official Coercion of Patronage Employecs to Campaign for Party-Endorsed Candidates, 84 HARv. L. Rev. 1547 (1971); Note, Political Patronage and the Independent Candidate, 66 Nw. U.L. REv. 390 (1971).

Of course judicial recognition of candidates' rights does not mean that those rights, like voting rights, are not subject to reasonable regulation, such as to age, residency, and citizenship. See, e.g., Kramer v. Union Free School Dist., 395 U.S. 621 (1969). Sec also Bullock v. Carter, 405 U.S. 134 (1972) (filing fees); Jenness v. Fortson, 403 U.S. 431 (1971) (petition requirements).

The failure to recognize the rights of candidates has several adverse consequences. First, it has caused confusion in the lower courts. Compare Heiser v. Rhodes, $305 \mathrm{~F}$. Supp. 269 (S.D. Ohio 1969), with Shakman v. Democratic Org. of Cook County, supra; White v. Sncar, supra; and Stapleton v. Clerk for City of Inkster, supra. Furthermore, if the rights of candidates are protected only because of their correlative relation to the rights of voters, then candidates may be required to demonstrate specifically how a particular state statute actually abridges the rights of a certain class of voters. Such an evidentiary barrier would unnecessarily impede the vindication of the interests of both the candidate and the voters. Finally, the theory of candidates' rights would provide a sounder constitutional foundation than presently exists for efforts to equalize the status of candidates in the electoral arena, such as limitations on contributions and expenditures. The constitutional issues raised by these proposals have been widely discussed. See, e.g., H. Penniman \& R. Winter, Campaign Finances: Two Views of the Political and Constiturional Implications (1971); A. Rosenthal, Federal ReguLation of Campaign Finance: Some Constitutional Questions (1972); Fleishman, Freedom of Speech and Equality of Political Opportunity: The Constitutionality of the Federal Campaign Act of 1971, 51 N.C. L. REV. 389 (1973). For a constitutional analysis of the manner in which public officeholder perquisites disadvantage challengers, entrench incumbents, and cause unfair elections, see Note, Congressional Perquisites and Fair Elections: The Case of the Franking Privilege, 83 YALE L.J. 1055, 1080-83 (1974). 
the New York Election Law also operates in a manner that deprives those voters and candidates of due process of law.

This denial of due process stems from the incompatibility of the partisanship of the election officials with the judicial, or quasi-judicial, nature of their positions. Nearly 50 years ago the Supreme Court held in Tumey $v$. Ohio"st that a "situation in which an official perforce occupies two practically and seriously inconsistent positions, one partisan and the other judicial, necessarily involves a lack of due process of law."s2 Tumey involved a practice in which persons charged with violating the Ohio Prohibition Statute were tried before judges whose salaries were supplemented by the fines obtained from convictions. The Court ruled that subjecting an individual to a trial before a judge with such a "direct, personal, substantial, pecuniary interest" in convicting him was a denial of due process. ${ }^{83}$ This decision was recently extended in Ward $v$. Village of Monroeville. ${ }^{84}$ In Ward, the mayor of Monroeville was the judge of the village traffic court; although the mayor's salary did not depend on the fines collected from convictions, thereby excluding any direct pecuniary interest, the Court held that his position as the village's chief financial officer was sufficient to disqualify him as a neutral judge. The Court stated the due process test for prejudice as whether the official's situation "would offer a possible temptation to the average man" to forget his legal obligations. ${ }^{85}$ Although Tumey and Ward involved criminal trials, the same standards of due process are also applicable to quasi-judicial proceedings or administrative adjudications. ${ }^{86}$

Two threshold questions therefore arise. First, are the New York

81. 273 U.S. 510 (1927).

82. Id. at 534 .

83. Id. at 523 .

84. 409 U.S. 57 (1972). But cf. Dugan v. Ohio, 277 U.S. 61 (1928).

85. Id. at 60 , citing Tumey v. Ohio, 273 U.S. at 532.

86. See Hannah v. Larche, 363 U.S. 420 (1960). which involved the issue of whether certain due process requirements must be extended to administrative proceedings of the United States Civil Rights Commission. The Supreme Court's opinion represents an attempt to delineate those types of administrative proceedings that could be considered to esercise sufficient "judicial power" to require adherence to due process standards. The Court announced the rule that "when governmental agencies adjudicate or make binding determinations which directly affect the legal rights of individuals, it is imperative that those agencies use the procedures which have traditionally been associated with the judicial process." Id. at 442.

"Adjudicate" seems to be the operative word. Due process standards were not extended to the Civil Rights Commission in Hannah because it was deemed to be merely an investigative body, not having an adjudicative function. 363 U.S. at 441 . See generally Gibson v. Berryhill, 411 U.S. 564 (1973); Pickering v. Board of Educ., 391 U.S. 563 (1967); Commonwealth Coatings Corp. v. Continental Cas. Co., 393 U.S. 145 (1968); Steele v. Louisville \& Nashville R.R. Co., 323 U.S. 192 (1944).

For an analysis of the several types of bias that may be sufficient to disqualify a judicial or administrative officer, see K. Davis, Administrative LAw TExr $\$ 12.04$, at 245-53 (1972) (" $[\mathrm{m}]$ ost of the law concerning disqualification because of interest applies with equal force to .... administrative adjudicators"). 
City election commissioners and inspectors partisan? Second, do they perform judicial, or quasi-judicial, functions?

There should be little doubt as to the issue of partisanship. Election officials in New York are selected on the basis of their political views by the party leaders; ${ }^{87}$ not only are such officials partisan, therefore, but they are also beholden to those who control the regular faction of the party. ${ }^{88}$ Moreover, the notion that the election procedure actually operates in a fair and bipartisan manner is a myth..$^{80}$ Even without the documented partisanship and misconduct that occurred in the Lowenstein-Rooney primary, the operation of the New York Election Law indicates that election officials are involved in a situation that presents at least a "possible temptation to the average man."

Less clear is the issue of whether the tasks performed by election commissioners and inspectors are sufficiently judicial in character to be within the scope of the Tumey-Ward due process test. In Socialist Workers Party $v$. Rockefeller, ${ }^{90}$ the only court directly to consider this question answered it in the negative. In 1970 members of the Socialist Workers Party challenged the New York Election Law, claiming it denied them due process by allowing partisan members of the Board of Elections to judge the sufficiency of nominating petitions filed by minority party candidates. The district court ruled Tumey and Ward inapplicable to the New York Election Law because "the tasks delegated to the election commissioners are basically ministerial, and subject to judicial review by an impartial court. Moreover, plaintiffs tender no specific examples of abuse." 11

This decision, while seemingly dispositive of the due process issue as it relates to election officials in New York, deserves closer consideration for at least three reasons. First, the court in Socialist Workers Party required the plaintiffs to document specific examples of abuse, even though the Supreme Court in Ward found a denial of due process upon a showing of potential prejudice unaccompanied by particular instances of actual improprieties. ${ }^{92}$ Moreover, the argument

87. See pp. 66-67 supra.

88. Id.

89. See pp. 64-65 supra.

90. 314 F. Supp. 984 (S.D.N.Y.), aff'd, 400 U.S. 806 (1970).

91. Id. at 997 .

92. Compare id. at 997, with 409 U.S. at 61-62. See also Pirincin v. Board of Elections, 368 F. Supp. 64, 77 (1973) (bias will not be inferred without proof of actual discrimination). Although the Court erred in Socialist Workers Party by requiring specific examples of abuse, it would be proper to require some showing of potential prejudice before a statute was declared unconstitutional on due process grounds. This potentiality can be inferred from the facts and circumstances of a particular situation 
that any injustice suffered by petitioners could be corrected by appeal was specifically rejected in Ward $^{93}$ Finally, a subsequent decision casts considerable doubt on the validity of the holding in Socialist Workers Party. Weiss $v$. Duberstein ${ }^{94}$ involved a challenge to the constitutionality of one of the provisions of the New York Election Law that govern the selection of election commissioners. In holding that a constitutional issue existed and that abstention by the district court was improper, the Court of Appeals for the Second Circuit cited at length the substantial duties and responsibilities of the New York City Board of Elections and stated the Board was "no mere clerical staff, nor are the tasks delegated to it merely ministerial.",95

Of course, not every act of the Board of Elections partakes of a judicial quality, but certainly some of the Board's acts do. Administrative agencies perform judicial functions, and hence are subject to due process requirements, when they "adjudicate or make binding determinations which directly affect the legal rights of individuals . . . . .98 Examples of powers exercised by the Board of Elections which come within this definition of judicial function include: removal for cause of appointed election officials; ${ }^{27}$ preparation of a list challenging those voters who have lost the right to register from a given address; ${ }^{98}$ determination that a voter is not entitled to an $a b$ -

and type of prejudice. In other cases, general background and history may be more important than the abstract character of the prejudice. But even with the highest standard-that of specific abuse-sufficient examples of discrimination exist to support a finding that the New York Election Law results in an unconstitutional denial of due process.

93. Writing for the Court, Justice Brennan held that that Ohio procedure could not "be deemed constitutionally acceptable simply because the State eventually offers a defendant an impartial adjudication. Petitioner is entitled to a neutral and detached judge in the first instance." Ward v. Village of Monroeville, 409 U.S. 57, 61-62 (1972).

94. 445 F.2d 1297 (2d Cir. 1971).

95. Id. at 1302 (emphasis supplied). Weiss is significant not only for the view it expresses of election commissioners, but also because it is another example of the anachronistic nature of the New York Election Law. Plaintiff Weiss challenged $\$ 31$ of the statute, which in $197 \mathrm{I}$ provided for the selection of election commissioners upon recommendations made by the county chairmen of the New York and Kings County committees of the two major political parties in the state. He argued that $\$ 31$ denied the Republican and Democratic County Committees of Bronx, Queens, and Richmond counties of the right to certify party members for appointment.

This version of $\$ 31$ had been enacted in the carly part of the 20th century, when New York and Kings Counties were the most populous counties in New York City. In 1900, 88 percent of the population of the city lived in Kings or New York County. But in 1971, the County Committees of Kings and New York enjoyed the same exclusive privilege, although their aggregate population consisted of only 56 percent of the total city population. 445 F.2d at 1300-0I. On remand from the Court of Appeals, Judge Frankel found the limitation on the certifying power to be unconstitutional. Civil No. C70-1200 (S.D.N.Y. Sept. 1, 1971), aff'd, 465 F.2d 1405 (2d Cir.), cert. denied, 409 U.S. 876 (1972). His decision was soon followed by corrective state legislation. See N.Y. Election Law \$ 31 (McKinney Supp. 1973).

96. Hannah v. Larche, 363 U.S. 420,442 (1960).

97. N.Y. Election LAw $\$ 45$ (McKinney 1964).

98. Id. $\$ 410$. 
sentee ballot; ${ }^{99}$ and resolution of objections to a petition, or certificate of designation, or nomination. ${ }^{100}$ Although not exhaustive, these enumerated responsibilities are indicative of the important decisions made by the Board of Elections that directly determine individual rights.

In their totality, the functions performed by election inspectors are also judicial in nature. The discretionary powers of these officers are enormous and relatively unchecked. ${ }^{101}$ It is no exaggeration to maintain that they actually control whether or not a person votes, and this certainly qualifies as a determination of the legal rights of individuals. ${ }^{102}$ This discretion assumes particular importance in light of the fact that a decision by an election inspector that deprives a voter of the franchise can only be overruled by a court order. ${ }^{103}$ The process of obtaining such an order is so time-consuming and inconvenient that it is unrealistic to expect many voters to pursue it. ${ }^{104}$ Hence, judicial review in this situation is simply not a realistic remedy for an aggrieved person. ${ }^{105}$

The partisan nature of election officials in New York is undeniable. The proposition that the tasks they perform are judicial, or quasijudicial, is supported by both logic and precedent. Therefore, the due process standards of Tumey and Ward should be applied to invalidate as unconstitutional the New York Election Law.

\section{Reform of the New York Election Law}

If, as this Note has argued, the New York Election Law is unconstitutional in its method of selecting election officials, the state must reconsider the issue of election administration and enact appropriate legislation. This section will outline briefly the considerations that should guide this effort. ${ }^{106}$

99. N.Y. Electron LAw $\$ \$ 117,117 a, 118$ (McKinney Supp. 1973).

100. N.Y. Election LaW $\$ 145$ (McKinney 1964).

101. See pp. 64-65 supra \& note 13 supra.

102. See id.; Note, supra note 28, at 662-63.

103. N.Y. ELECTION LAw $\$ 331$ (MICKinney 1964).

104. For reports of the difficulties experienced by challenged voters seeking court orders, and the attempts by the Board of Elections to provide judicial review, see N.Y. Times, Oct. 31, 1972, at 37, col. 1; id., Sept. 20, 1972, at 1, col. 3; N.Y. Post, Sept. 20, 1972 at 3 , col. 1 .

105. The denial of due process may also be viewed as an infringement of the rights of candidates as well as those of voters. See note 80 supra. A candidate wishing to challenge an election as violative of due process confronts many of the same practical difficulties as a voter. The Lowenstein suit represents a type of litigation that few candidates can undertake.

106. A comprehensive description of any particular system for selecting election officials-including specifications as to compensation, training, qualifications, and term 
There are two basic approaches to election administration. A state can strive to attain fair elections through a system based on either partisanship or nonpartisanship. These alternatives present the basic policy questions here at issue, and the choice between them will determine the characteristic features of the state system of election administration.

To describe a system as based on the principle of partisanship does not imply that it necessarily operates in a partisan or biased manner. ${ }^{107}$ A system founded on partisanship seeks to secure fair elections through the checks and balances created by placing officials of differing political views in administrative positions. ${ }^{108}$ Whether bipartisan $^{100}$ or multipartisan, ${ }^{110}$ such a system is premised on the belief that political competition will adequately deter electoral misconduct.

The inherent weaknesses of a partisan system, and especially a bipartisan one, have already been demonstrated. ${ }^{111}$ It is not inconceivable, however, that a partisan system could be established that is effective and hence constitutionally permissible. For a partisan system to operate effectively, it must be sufficiently flexible to allow for representation on election boards of all significant elements of the electorate. A system based on the check provided by competitive impulses must insure that the election administration accurately reflects the political competition in the electorate. ${ }^{112}$ Hence, provision must be made for the representation of both the internal party factions in primary elections, and minority parties and independents in general elections. Limitations on the type or number of electoral groups that may be represented ${ }^{113}$ are inconsistent with the underlying principle of the partisan system and may also result in an unconstitutional system of unfair election procedures.

As a guarantee of electoral fairness, the basic alternative to reliance on partisan competition is a nonpartisan system. ${ }^{114}$ The major ad-

of office-is beyond the scope of this Note. Instead, the basic policy choices, rather than detailed plans for their implementation, are outlined and evaluated. For the most detailed treatment of the problem of election administration, see J. HARRIs, supra note 27.

107. See note 11 supra.

108. See p. 68 supra.

109. See note 41 supra.

110. See note 40 supra.

111. See pp. 71-72 supra.

112. See note 11 supra.

113. Presumably, a de minimis test would be permissible. See, e.g., Bullock v. Carter, 405 U.S. 134 (1972), where the Court recognized that the state had some interest in discouraging frivolous candidates from burdening election administration and the voters. The means used to deter the frivolous, though, must be narrowly drawn so as not to infringe on fundamental rights.

114. See, e.g., Cat. Elections Code $\$ 1615$ (West 1961). 
vantage of this type of system is that it eliminates partisan political considerations from election administration. Nonpartisanship is premised on the theory that selection of election officials on a basis other than party affiliation and loyalty will ultimately lead to elections being administered in a more neutral and disinterested manner. Moreover, nonpartisanship eliminates any constitutional problems that arise from the exclusion of certain segments of the electorate from election administration. ${ }^{115}$

The principal disadvantage of the nonpartisan approach is that it may place a greater burden on the system of election administration. For example, in New York City alone, 23,000 inspectors are needed on election day. ${ }^{116}$ Under the current New York law, recruitment of election officials is made easy by requiring the parties to provide the necessary manpower. ${ }^{117}$ However, the greater burden resulting from a nonpartisan system may be outweighed by the value to society of democratic elections administered both fairly and competently by officials selected on a basis other than party loyalty. Moreover, the state may be able to employ a variety of techniques to minimize the burden. ${ }^{118}$

Within constitutional limits, the ultimate choice between the two basic alternatives is entrusted to the state legislature. A prudent decision can be made only after careful and thorough consideration of political and financial realities. Such a process should begin immediately in order to correct the inadequacies of the anachronistic and unconstitutional New York Election Law.

\section{Conclusion}

The right of suffrage is a meaningless formality where fair elections do not exist. Although designed to insure fairness, the manner in which New York selects those who administer its elections actually insures partisan control of the state's election machinery. The legal

115. See pp. 75-77 supra.

116. Interview with David Dinkins, former President of the New York City Board of Elections, in New York City, Nov. 2, 1973.

117. See p. 66 supra.

118. A variety of mechanisms could be used to produce the number of people needed to serve as election officials. Certain civil service employees could be diverted from their regular work for one day. The state legislature could declare election day a public holiday, thereby creating a vast reservoir of individuals with the ability to volunteer time. Public schools are regularly used as polling places. Public school teachers, then, are an obvious labor force that may be available. Arrangements could be made with major institutional employers to pay employees for days spent serving as election officials, just as many now do for employees serving on juries. 
result of this statutory scheme is a system that violates the Equal Protection Clause by unconstitutionally burdening the fundamental rights to vote and to associate. Furthermore, due process of law is denied by a statute that requires the electoral rights of voters and candidates to be determined by partisan individuals performing judicial, or quasi-judicial, functions.

Various reforms of the New York Election Law are both desirable and feasible. It is the responsibility of the state legislature to determine and enact appropriate reforms in order to protect the fundamental value of fair elections in a democracy. 